\title{
Effects of Organic Amendments on Soil Aggregate Stability and Microbial Biomass in a Long-Term Fertilization Experiment (IOSDV)
}

\author{
Gábor Csitári ${ }^{1}\left[\right.$, Zoltán Tóth ${ }^{2, *}$ [i] and Mónika Kökény ${ }^{2}$ \\ 1 Institute of Physiology and Nutrition, Georgikon Campus, Keszthely, \\ Hungarian University of Agriculture and Life Sciences, 2100 Gödöllő, Hungary; csitari.gabor@uni-mate.hu \\ 2 Institute of Agronomy, Georgikon Campus, Keszthely, Hungarian University of Agriculture and Life Sciences, \\ 2100 Gödöllő, Hungary; kmoni1231@gmail.com \\ * Correspondence: toth.zoltan@uni-mate.hu
}

Citation: Csitári, G.; Tóth, Z.; Kökény, M. Effects of Organic Amendments on Soil Aggregate Stability and Microbial Biomass in a Long-Term Fertilization Experiment (IOSDV). Sustainability 2021, 13, 9769. https://doi.org/10.3390/su13179769

Academic Editor: Nádia

Luísa Castanheira

Received: 30 July 2021

Accepted: 26 August 2021

Published: 31 August 2021

Publisher's Note: MDPI stays neutral with regard to jurisdictional claims in published maps and institutional affiliations.

Copyright: (c) 2021 by the authors. Licensee MDPI, Basel, Switzerland. This article is an open access article distributed under the terms and conditions of the Creative Commons Attribution (CC BY) license (https:// creativecommons.org/licenses/by/ $4.0 /)$.

\begin{abstract}
The effect of two types of organic amendment (manure and straw incorporation) and various doses (0-200 $\mathrm{kg} \mathrm{N}^{*} \mathrm{ha}^{-1}$ ) of mineral $\mathrm{N}$ fertilization on microbial biomass $\mathrm{C}$ (MBC), aggregate stability (AS), soil organic C (SOC) and grain yield were investigated in an IOSDV long-term fertilization experiment (Keszthely, Hungary). This study was conducted during years 2015-2016 in a sandy loam Ramann-type brown forest soil (Eutric Cambisol according to WRB). Organic amendments had a significant effect on AS, MBC and SOC, increased their values compared to the unamended control. The organic amendments showed different effects on AS and MBC. AS was increased the most by straw incorporation and MBC by manure application. The magnitude of temporal variability of AS and MBC differed. Presumably, the different effects of organic amendments and the different degrees of temporal variability explain why there was only a weak (0.173) correlation between AS and MBC. AS did not correlate with SOC or grain yield. MBC correlated (0.339) with SOC but not with the grain yield. The $\mathrm{N}$ fertilizer dose did not have a significant effect on $\mathrm{AS}$ and $\mathrm{MBC}$, but had a significant effect on SOC and grain yield.
\end{abstract}

Keywords: soil aggregate stability; microbial biomass; long-term fertilization experiment; IOSDV; organic amendment; $\mathrm{N}$ fertilization

\section{Introduction}

Soil is a natural resource and must be sustainably managed for the future of mankind. Among a wide variety of soil properties, the soil structure is of great importance in the field of soil resource management. Good soil structure is the most desirable aim for sustaining agricultural productivity and for preserving environmental quality [1]. The role of soil structure in controlling soil ecosystem functions and the feedback between soil structure and soil (micro)organism are generally recognized for a long time but not fully understood $[2,3]$.

Aggregates. Soil structure depends on the amount and distribution of stable aggregates. Soil aggregation is the process by which aggregates of different sizes are joined and held together by different organic and inorganic materials. Due to the hierarchical nature of soil structure, different mechanisms of aggregation operate in different size classes of aggregates. Macro-aggregates (greater than $250 \mu \mathrm{m}$ ) are held together largely by fine roots and fungal hyphae. Micro-aggregates $(20-250 \mu \mathrm{m})$ consist largely of particles 2-20 $\mu \mathrm{m}$ diameter bonded together by various cements including persistent organic materials and crystalline oxides and highly disordered aluminosilicates $[1,4,5]$. The term aggregate stability (AS) is used in the literature in a different sense. We use this term (AS) only to refer to macro-aggregate stability. Water-stable and wet-aggregate stability are also commonly used terms in the literature and they refer to macro-aggregate stability. Many different 
methods exist for measuring soil aggregate stability. In our experiments, the wet sieving technique was used to separate macro-aggregates.

Climate is one of the soil-forming factors that strongly influences the soil type and the degree of soil aggregation [1]. The climate can directly influence aggregate stability through its action on soil moisture [6] and indirectly through seasonal stimulation of microbial activity [7]. Changes in water content (wetting-drying cycles) and in air temperature (freezing-thawing cycles) influence the formation and destruction of soil structure in a dynamic way. These cycles are the main reasons for the seasonal variation of aggregate stability. Chan et al. (1994) found that seasonal fluctuations in aggregate stability were observed under all applied treatments and they were greater than the differences detected between the different tillage and cropping treatments [8]. Seasonal variations of aggregate stabilities have been observed since the 1990s [6,9-12] and this topic is still frequently researched [13-15]. Aggregate stability is usually lowest during winter and increases in spring but often there is no clear tendency [6]. In the context of climate, the amount of organic matter incorporated into the soil is also an important factor in seasonal variation [16].

Biological factors of soil aggregation include plant roots, soil microbes, and soil fauna [1]. Correlation can be found between the amounts of roots or root exudates and the aggregate stability [17,18]. Among soil microbes, fungi, particular arbuscular mycorrhizal (AM) fungi are the main aggregating organisms $[19,20]$. The impact of soil organisms on aggregate formation was first conceptualized in the form of the hierarchical model of soil aggregation [4]. The interactions between soil particles and microorganisms are studied at many levels, from pots to field experiments $[1,5,21]$. Significant correlation between microbial biomass and macro-aggregate stability can be found frequently [22].

Agricultural managements include tillage, irrigation, inorganic fertilization, organic amendments, crop types and crop rotation [1]. Among them, the role of organic amendments is mentioned here. Soil organic matter (SOM) is a key factor in soil aggregate stability [23]. The effects of SOM on macro-aggregates are mainly indirect, and based on the products (e.g., polysaccharides, hyphae) of stimulated microorganisms. The effects of SOM on aggregate stability differ between the various soils, and the extent of the effect depends on the soil chemical properties (mainly clay mineralogy), climate, vegetation and soil management. A wide range of organic materials has been studied to investigate their impact on aggregation [16,24,25]. It is widely accepted that organic amendments have a positive effect on soil aggregation [26-28]. The very important role of SOM content on macro-aggregate stability and soil productivity has led to discovering various ways to manage and increase SOM. The sizes of effect vary depending on the form, dose and frequency of organic amendment [29-31]. The effects of crop residue incorporation and organic manure on macro-aggregate stability also differ. Di Gléria et al. (1957, cit Huisz 2002) stated that the incorporated organic amendments will only stimulate the formation of water stable aggregates if their decomposition are processed in the soil from the first stages [32,33]. According to their theory, the authors observed that animal manure only slightly increased the aggregate formation.

Soil microbial biomass. The soil microbial biomass is the living component of SOM. Although the soil microbial biomass only consists of $1-5 \%$ of organic $C$ and $1-6 \%$ of total $\mathrm{N}$ [34], it plays important roles in the soil. It is both a source and sink for C, N, S and P, performs the formation and breakdown of humic materials and takes part in the aggregate formation and degradation [35]. The overriding control over microbial biomass in soils is the C availability [36-38]. Microbial biomass has been found to be tightly coupled to the quantity of SOM and to quantity and quality of $C$ inputs, both in agricultural and unmanaged ecosystems [37,39].

The soil microbial biomass is not a static entity, and its temporal dynamics are likely to be extremely important in determining the extent of release of immobilized labile nutrients [40]. Seasonal fluctuations in soil microbial biomass can occur due to changes in the amount of substrates, temperature and moisture. Many researchers have recorded 
seasonal fluctuations in microbial biomass under both pastoral and arable conditions, but trends in microbial biomass are not well understood. Such seasonal variations must be taken into account when microbial biomass data is compared. Seasonal fluctuations of microbial characteristics are comparable with, or larger than, the effects of management practices [41]. The coefficient of variation $(\mathrm{CV})$ of the microbial biomass $\mathrm{C}$ or $\mathrm{N}$ over the duration of a study is a proper index, and this measure is one of the most popular indices of temporal variability [40].

The effects of mineral fertilizers and organic amendments on the SOM and microbial biomass were investigated for a long time. A number of recent reviews and meta-analysis have been published [27,30,42-44]. In the meta-analyses of Geisseler and Scow (2014) the mineral fertilizer application led to a $15.1 \%$ increase in microbial biomass C (MBC), above the levels in unfertilized control treatments overall [43]. The magnitude of the effects of fertilization on MBC was $\mathrm{pH}$ dependent. Mineral fertilization also increased SOC content by an average of $8.5 \%$. It was suggested that SOC is a major factor contributing to the overall increase of $\mathrm{MBC}$, as the mineral fertilizer had no significant effect on the proportion of SOC contributions by microbial biomass [43]. Körschens et al. (2013) obtained a similar result analyzing data from agricultural long-term experiments located in Europe [45]. In their analysis, mineral NPK fertilization increased SOC by $10 \%$ compared to the control treatment [45]. Bai et al. (2018) demonstrated in their analysis, based on 424 observations, that organic matter additions favorably affected SOC, MBC and AS [30]. Kallenbach and Grandy (2011) found in their meta-analysis that organic amendments increased MBC by $36 \%$ across all observations [42]. Agricultural strategies that deliver high rates of exogenous $C$ to the soil return of plant residues often have high concentrations of MBC in soil [39]. Microbial responses depend upon the type and rate of inputs, as well as soil characteristics [42]. Predicting MBC responses to organic amendments remains challenging as soil environments are complex and show variable responses to organic amendments.

Long-term fertilization trials. Effects in soil are frequently masked by local and temporal fluctuations. Many effects in the soil evolve slowly, so it is necessary to conduct longterm fertilization trials [39]. Many long-term trials were established primarily to study the impact of fertilizers on crop production. Long-term fertilization experiments provide a solid basis for studying the relationship between organic and inorganic fertilization, microorganism content and soil aggregate stability. In our research we used the soils of an IOSDV long-term experiment set up in 1984 near Keszthely, Hungary. IOSDV experiments were set up in 15 different locations in 8 countries following the same principles [45]. Publications on IOSDV experiments mainly concerned changes in crop yields and soil organic matter content $[44,46-48]$, but there are a number of articles which deal with aggregate stability $[49,50]$ or soil microbial biomass [51].

\section{Aim of Study}

The aim of our research was to investigate the effect of inorganic fertilization and organic matter amendments (organic manure and plant incorporation) on soil aggregate stability and microbial biomass content in Ramann-type brown forest soil (WRB: Eutric Cambisol). The relationships between soil microbial biomass and aggregate stability were also examined.

\section{Materials and Methods}

\subsection{Characteristics of the Field Experiment}

The investigation took place in the international long-term fertilization experiment (IOSDV) located in Keszthely, Hungary $\left(46^{\circ} 45^{\prime} \mathrm{N}, 17^{\circ} 14^{\prime} \mathrm{E}\right)$ at $115 \mathrm{~m}$ above sea level. The site is situated in the continental climate zone in Central Europe. It is often characterized as Pannonian climate zone also. The mean annual air temperature is $10.8^{\circ} \mathrm{C}$, the annual precipitation is $650 \mathrm{~mm}$ (average of last 50 years). During the period of study mean annual air temperature was 11.8, 11.4 and $11.2{ }^{\circ} \mathrm{C}$ in 2014, 2015 and 2016, respectively. Annual precipitation was 877, 591 and $779 \mathrm{~mm}$ in the previous order. Therefore, the years 2014 
and 2016 can be characterized as wet, 2015 as a moderately dry year, in terms of water supply. In the growing seasons of the different crops mean temperature and amount of rainfall was $17.0^{\circ} \mathrm{C}$ and $616 \mathrm{~mm}$ in 2014 (May 2014-September 2014 for maize), $8.8^{\circ} \mathrm{C}$ and $353 \mathrm{~mm}$ (October 2014-June 2015, for winter wheat), as well as $8.8^{\circ} \mathrm{C}$ and $553 \mathrm{~mm}$ (October 2015-June 2016, for winter barley).

The soil texture is classified as sandy loam. Soil plasticity index according to Arany is 36-37. The soil type is Ramann s brown forest soil, according to WRB it is a Eutric Cambisol [52]. Organic C content is $1.0 \%$, total $\mathrm{N}$ is $0.12 \%, \mathrm{AL}\left(\mathrm{P}_{2} \mathrm{O}_{5}\right)$ is $60-80 \mathrm{mg}^{*} \mathrm{~kg}^{-1}$, $\mathrm{AL}\left(\mathrm{K}_{2} \mathrm{O}\right)$ is $140-160 \mathrm{mg}^{*} \mathrm{~kg}^{-1}, \mathrm{pH}_{(\mathrm{KCl})}$ is $6.8-7.0$.

The "International Mineral and Organic Nitrogen Fertilization Trial" (Der Internationale Organische Stickstoffdauerdüngungversuch) was set up in 1983, while the first harvest year was 1984. In the experiment a three course cereal crop rotation is rotated since the beginning. The crop rotation consists of maize, winter wheat and winter barley in this order. During the period of this study maize (2014), winter wheat (2015) and winter barley (2016) plots were sampled in order to stay on the same plots avoiding error due to spatial heterogeneity of soil as well as to be able to estimate residual effect of organic manure. Since the beginning of the experiment the long-term effect of more than 30 years and 10 rotation period could succeed. The experiment is a bifactorial experiment having a strip plot design and 3 replications. The two factors are organic amendments and mineral $\mathrm{N}$ fertilization. Two types of organic amendment treatment were applied as a supplement to mineral $\mathrm{N}$ fertilization. As a control only mineral $\mathrm{N}$ treatments were applied also. Straw was removed and there was no added organic matter in the "No" (control) treatment (only mineral $\mathrm{N}$ treatments are applied); straw was removed, but farmyard manure (35 $\mathrm{t}^{*} \mathrm{ha}^{-1}, 0.5 \% \mathrm{~N}$, once every three years, before the maize) was added in the "Manure" treatment once in the 3 year rotation before maize; and straw was incorporated in the "Straw" treatment in each year. The straw incorporation was completed with $10 \mathrm{~kg} \mathrm{~N}^{*} \mathrm{t} \mathrm{straw}^{*} \mathrm{ha}^{-1}$.

There were five mineral $\mathrm{N}$ rates (N0, N1, N2, N3 and N4) for all three crops in the crop rotation ( $\mathrm{N}$ is applied each year according to the crop):

N0: no mineral $\mathrm{N}$;

$\mathrm{N} 1: 70 \mathrm{~kg}^{*} \mathrm{ha}^{-1}$ for maize, $50 \mathrm{~kg}^{*} \mathrm{ha}^{-1}$ for winter wheat and $0 \mathrm{~kg}^{*} \mathrm{ha}^{-1}$ for winter barley;

N2: $140 \mathrm{~kg}^{*} \mathrm{ha}^{-1}$ for maize, $100 \mathrm{~kg}^{*} \mathrm{ha}^{-1}$ for winter wheat and $0 \mathrm{~kg}^{*} \mathrm{ha}^{-1}$ for winter barley; N3: $210 \mathrm{~kg}^{*} \mathrm{ha}^{-1}$ for maize, $150 \mathrm{~kg}^{*} \mathrm{ha}^{-1}$ for winter wheat and $40 \mathrm{~kg}^{*} \mathrm{ha}^{-1}$ for winter barley; N4: $280 \mathrm{~kg}^{*} \mathrm{ha}^{-1}$ for maize, $200 \mathrm{~kg}^{*} \mathrm{ha}^{-1}$ for winter wheat and $80 \mathrm{~kg}^{*} \mathrm{ha}^{-1}$ for winter barley.

Ploughing, cultivation, seeding rate, sowing method and phosphorus and potassium fertilization rates $\left(100 \mathrm{~kg}^{*} \mathrm{ha}^{-1} \mathrm{P}_{2} \mathrm{O}_{5} \%\right.$ and $\left.100 \mathrm{~kg}^{*} \mathrm{ha}^{-1} \mathrm{~K}_{2} \mathrm{O}\right)$ are the same for all plots. Conventional soil tillage system is applied for seedbed preparation based on shallow stubble tillage, followed by ploughing $(27 \mathrm{~cm})$ in the Autumn, then secondary tillage and seedbed preparation. Plant density is 72, 5000 and 4500 thousand plant per hectare for maize, winter wheat and winter barley, respectively. Plot size is $48 \mathrm{~m}^{2}(6 \mathrm{~m} \times 8 \mathrm{~m})$. All treatments are in 3 replicates [53].

The experimental field is rainfed, no irrigation was applied neither since nor before the beginning of the trial.

Soil samplings $(0-30 \mathrm{~cm})$ were performed plot by plot four times throughout the study period (30 April and 27 October in 2015, 13 April and 29 October 2016). In this paper, the results of 2015 and 2016 are evaluated when winter cereals (winter wheat and winter barley) were grown in the rotation, since these crops are grown during similar time period and under very similar field preparations. In the case of maize (2014), soil tillage applications in the spring results in fresh soil disturbance in April making impossible to compare soil physical and biological parameters between different years in this period. Wet soil samples were stored at $4{ }^{\circ} \mathrm{C}$ until the determination of soil microbial biomass. Air dried soils were used for the other measurements. 


\subsection{Measurements}

Microbial biomass carbon (MBC) contents were measured using the fumigation extraction method, according to Vance et al. (1987) [54].

Soil aggregate stability was determined by wet sieving. In our studies we used a simple indicator of aggregate stability, the percentage of waterproof macro-aggregates (larger than $250 \mu \mathrm{m}$ ). Samples were prepared using the Kemper and Koch (1966) method, using the fraction sieved between 1 and $2 \mathrm{~mm}$ [55]. Samples were sieved in an air-dried state on a Retsch AS200 Digit sieve, and then a Wet Sieving Apparatus (Eijkelkamp Agrisearch Equipment, Giesbeek, The Netherlands) was used to determine the aggregate fractions larger than $250 \mu \mathrm{m}$.

The determination of soil organic carbon content (SOC) was carried out by wet combustion method in sulfuric acid using potassium-dichromate for oxidizing SOC according to Tyurin in 2013 [56,57]. As SOC changes very slowly and no further measurements were taken, these SOC values were used in all the comparisons.

\subsection{Statistical Analysis}

The significance of the differences between treatments was estimated by one-way ANOVA and Tukey testing, correlation between factors was estimated by Pearson correlation, using the software package SPSS Student Version 15.0 (SPSS Inc., Chicago, IL, USA). Correlation was regarded as weak (between 0.1-0.3), moderate (between 0.3-0.7) and strong (between 0.7-1.0). An effect with $p>0.05$ was considered significant. Coefficient of variation (CV), also known as relative standard deviation (RSD), is a standardized measure of dispersion of frequency distribution. It is often expressed as a percentage, and is defined as the ratio of the standard deviation to the mean. Partial Eta squared obtained from ANOVA used to quantify the effect of a factor. To calculate partial Eta squared the explained variance divided by the sum of the explained variance and the error variance. Partial eta squares are not additive, and if added, may sum to over 1.00. An effect of $>0.100$ partial Eta squared was regarded considerable in our study.

\section{Results}

The aim of our research was to reveal the relationship between the aggregate stability (AS), soil microbial biomass C (MBC) and soil organic carbon (SOC). The effects of four different factors on these soil properties were investigated. The four factors were the year, the season, the organic amendment and the $\mathrm{N}$ fertilizer dose. In our experiment, the year factor means different crops and different pre-crops, as well as different residual effect of FYM application in addition to different weather conditions. Besides the AS, MBC and SOC, the effects of the four factors on the crop yield were also investigated. Grain yield is the most important agronomic parameter, it correlates the plant biomass and gives a rough estimate of the amount of organic $\mathrm{C}$ incorporated into soil.

Four-factor ANOVAs were performed and the results showed that AS was influenced by year, organic amendment and season. Organic amendment* $\mathrm{N}$ fertilizer dose interaction also had significant effects on AS. MBC was significantly influenced by year and organic amendment. The year*season, year*organic amendment, year* $\mathrm{N}$ fertilizer dose, season ${ }^{*}$ organic amendment, season ${ }^{*} \mathrm{~N}$ fertilizer dose interactions also had significant effects on MBC. The $\mathrm{N}$ fertilizer dose had no significant effect on neither MBC nor AS. SOC were significantly influenced by the organic amendment and $\mathrm{N}$ fertilizer dose. There was neither seasonal nor yearly measurement of SOC. The grain yields were significantly influenced by the year and $\mathrm{N}$ fertilization dose. Beyond the weather, the year factor includes different crop species too: winter wheat in 2015 and winter barley in 2016. According ANOVA organic amendments had no significant effect $(p=0.066)$ on grain yield but the Duncan-test shown different groups by organic amendments in grain yields.

The means and CV values of AS, MBC, SOC and grain yields of the different treatments are shown in Table 1. CV values represent the magnitude of the variance of the variables, expressed as a percentage of the mean. The results of the Tukey test performed to determine 
which means differed significantly from one another, are also presented in Table 1. Due to the significant interactions of the yearly and seasonal factors, the averages of sampling time were also included in Table 1 . The averages reported in Table 1 do not show the range of the variables. These ranges are the following: AS: $15.2-76.8 \%$; MBC: $47.4-396.3 \mu \mathrm{g} \mathrm{C}^{*} \mathrm{~g}^{-1}$ dried soil; SOC: $1.03-1.43 \%$; grain yield 1.80-9.26 $\mathrm{t}^{*} \mathrm{ha}^{-1}$.

Table 1. Averages and CV-s of aggregate stability (AS), microbial biomass carbon (MBC), soil organic carbon (SOC) and grain yield. Bold letters show there is a significant difference between the averages. Letters after the average values denote the results of Tukey tests. $n$ (numbers of data) is 180 for AS and MBC.

\begin{tabular}{|c|c|c|c|c|c|c|c|c|}
\hline Factor & $\begin{array}{c}\text { AS } \\
\text { Average (\%) }\end{array}$ & $\begin{array}{l}\text { AS } \\
\text { CV }\end{array}$ & 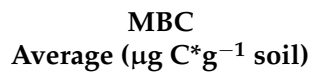 & $\begin{array}{c}\text { MBC } \\
\text { CV }\end{array}$ & $\begin{array}{c}\text { SOC } \\
\text { Average (\%) }\end{array}$ & $\begin{array}{l}\text { SOC } \\
\text { CV }\end{array}$ & $\begin{array}{c}\text { Grain Yield } \\
\text { Average }\left(t^{*} \mathrm{ha}^{-1}\right)\end{array}$ & $\begin{array}{c}\text { Grain Yield } \\
\text { CV }\end{array}$ \\
\hline \multicolumn{9}{|l|}{ year } \\
\hline 2015 & $43.4 \mathrm{a}$ & 25.3 & $196.1 \mathrm{a}$ & 33.7 & & & $6.44 \mathrm{a}$ & 28.1 \\
\hline 2016 & $58.2 \mathrm{~b}$ & 16.3 & $225.0 \mathrm{~b}$ & 34.5 & & & $4.04 \mathrm{~b}$ & 26.0 \\
\hline \multicolumn{9}{|l|}{ season } \\
\hline spring & $56.7 \mathrm{a}$ & 18.5 & 204.8 & 32.4 & & & & \\
\hline autumn & $45.1 \mathrm{~b}$ & 26.8 & 216.3 & 36.8 & & & & \\
\hline \multicolumn{9}{|c|}{ organic amendment } \\
\hline no & $48.3 \mathrm{a}$ & 28.6 & $171.9 \mathrm{a}$ & 36.0 & $1.125 \mathrm{a}$ & 5.8 & 5.18 & 38.9 \\
\hline manure & 50.7 a & 21.5 & $252.6 \mathrm{c}$ & 26.7 & $1.288 \mathrm{~b}$ & 7.2 & 5.58 & 35.4 \\
\hline straw & $53.7 \mathrm{~b}$ & 23.6 & $200.7 b$ & 33.7 & $1.144 \mathrm{a}$ & 3.1 & 4.97 & 34.6 \\
\hline \multicolumn{9}{|c|}{$\mathrm{N}$ fertilizer dose } \\
\hline N0 & $51.7 \mathrm{a}$ & 27.7 & $218.9 \mathrm{a}$ & 33.6 & $1.158 \mathrm{a}$ & 7.9 & $3.49 \mathrm{a}$ & 36.8 \\
\hline N1 & $51.6 \mathrm{a}$ & 25.6 & $224.2 \mathrm{a}$ & 31.1 & $1.200 \mathrm{ab}$ & 8.1 & $4.99 \mathrm{~b}$ & 25.9 \\
\hline N2 & $48.7 \mathrm{a}$ & 24.2 & $205.3 \mathrm{a}$ & 31.9 & $1.207 \mathrm{~b}$ & 10.1 & $5.98 \mathrm{bc}$ & 31.5 \\
\hline N3 & $51.6 \mathrm{a}$ & 21.9 & $204.0 \mathrm{a}$ & 39.3 & $1.183 \mathrm{ab}$ & 7.6 & $6.03 c$ & 34.1 \\
\hline N4 & $50.8 \mathrm{a}$ & 25.6 & $200.3 \mathrm{a}$ & 38.6 & $1.180 \mathrm{ab}$ & 7.8 & $5.74 \mathrm{bc}$ & 30.5 \\
\hline \multicolumn{9}{|c|}{ sampling time (year*season) } \\
\hline 2015 spring & $50.0 \mathrm{~b}$ & 17.0 & $175.1 \mathrm{a}$ & 26.8 & & & & \\
\hline 2015 autumn & $36.9 \mathrm{a}$ & 24.9 & $217.1 \mathrm{~b}$ & 34.8 & & & & \\
\hline 2016 spring & $63.4 \mathrm{c}$ & 11.8 & $234.5 \mathrm{~b}$ & 29.9 & & & & \\
\hline 2016 autumn & $53.2 \mathrm{~b}$ & 16.0 & $215.4 \mathrm{~b}$ & 39.0 & & & & \\
\hline total & 50.9 & 25.0 & 210.5 & 34.8 & 1.186 & 8.4 & 5245 & 36.3 \\
\hline
\end{tabular}

AS and MBC similarly changed by year: their averages were higher in the second year. AS showed significant seasonal change, however, $\mathrm{MBC}$ revealed none. The averages in the different sampling times demonstrate that the averages of AS in spring were higher in both years. For MBC, the two years were different: in 2015 the fall value was higher, in 2016 the spring value.

The effect of straw incorporation was similar: means of AS and MBC were higher than in the control. The effect of manure was different when comparing AS and MBC. Means of AS in manure treatment did not differ from the control, whereas means of MBC were the highest in manure treatment. The two different organic amendments had different effects on SOC: manure treatment significantly increased the amount of SOC, while straw incorporation treatment had no significant effect.

$\mathrm{N}$ fertilization dose had no significant effect neither on AS nor on $\mathrm{MBC}$ but it had a significant effect on SOC and on grain yield. The highest values of SOC and grain yields could be found in different doses of $\mathrm{N}$ fertilizer treatment. N1 and N2 doses caused the highest SOC values, while N2 and N3 doses produced the highest grain yield.

The values of partial Eta squared, obtained from ANOVA, were used to quantify the effect of factors on AS, MBC, SOC and grain yield. An effect with partial Eta squared $>0.100$ was regarded considerable and is indicated in bold in Table 2. In cases of AS, MBC and SOC the significant ( $p=0.005$ level) factors had a considerable effect. It means that effects of year and organic amendment on $\mathrm{MBC}$, the effects of year, season and organic amendment on AS and the organic amendment on SOC were considerable. An exception was found in case of the grain yield, where a non-significant interaction (year*organic amendment ${ }^{*} \mathrm{~N}$ fertilizer dose) also had a considerable effect. The most influential factor for MBC was the organic amendment, while for AS it was the year and season. Organic amendment and N 
fertilizer dose effected significantly on SOC, but organic amendment had a much greater effect size than $\mathrm{N}$ fertilization. The effect size of year and $\mathrm{N}$ fertilization were the highest in cases of the grain yield.

Table 2. The magnitudes and their significances of effect sizes (partial Eta squared) on the AS, MBC, grain yield and SOC. An effect of $>0.100$ Eta was regarded considerable (important) and is indicated in bold. The significance values are in parenthesis. $n$ (numbers of data) is 180 for AS and MBC.

\begin{tabular}{ccccc}
\hline \multirow{2}{*}{ Factor } & \multicolumn{4}{c}{ Partial Eta Squared (Significance) } \\
\cline { 2 - 5 } & AS & MBC & SOC & Grain Yield \\
\hline year (Y) & $0.592(0.000)$ & $0.130(0.000)$ & - & $0.685(0.000)$ \\
season (S) & $0.470(0.000)$ & $0.023(0.095)$ & - & - \\
organic amendment (O) & $0.111(0.001)$ & $0.439(0.000)$ & $0.561(0.000)$ & $0.087(0.066)$ \\
N fertilizer dose (N) & $0.032(0.420)$ & $0.058(0.122)$ & $0.068(0.075)$ & $0.597(0.000)$ \\
year*season & $0.014(0.201)$ & $0.143(0.000)$ & - & - \\
year*organic amendment & $0.017(0.350)$ & $0.158(0.000)$ & - & $0.069(0.119)$ \\
year*N fertilizer dose & $0.023(0.593)$ & $0.095(0.017)$ & - & $0.203(0.008)$ \\
season*organic & $0.043(0.072)$ & $0.380(0.000)$ & - & - \\
amendment & $0.029(0.469)$ & $0.088(0.025)$ & - & - \\
season*N fertilizer dose & $0.025(0.000)$ & $0.080(0.247)$ & $0.051(0.600)$ & $0.227(0.040)$ \\
organic amendment*N & $0.302(0.70)$ & 0.584 & 0.815 \\
fertilizer dose & 0.76 & 0.738 & {$[0.549]$} & {$[0.726]$} \\
R Squared & {$[0.643]$} & {$[0.609]$} &
\end{tabular}

The nutrient levels in soil are important when studying the effects of organic amendments and other factors therefore the effects of the factors are also reported by $\mathrm{N}$ fertilizer doses (Table 3). In cases of AS there is no difference between the $\mathrm{N}$ doses, while in cases of MBC the effect size of the year and season is different. Only at low N levels (N0 and N1) does the year and season have a significant effect on MBC. Similar to the MBC, the effect of organic amendment on grain yield is only significant at low $\mathrm{N}$ levels ( $\mathrm{N} 0$ and $\mathrm{N} 1$ ).

Table 3. The magnitudes and their significances of effect sizes (partial Eta squared) on the AS, MBC, grain yield and SOC on the different $\mathrm{N}$ fertilization levels. An effect of $>0.100$ Eta was regarded considerable (important) and is indicated in bold. The significance values are in parenthesis.

\begin{tabular}{|c|c|c|c|c|}
\hline \multirow{2}{*}{ Factor } & \multicolumn{4}{|c|}{ Partial Eta Squared (Significance) } \\
\hline & AS & MBC & SOC & Grain Yield \\
\hline \multicolumn{5}{|l|}{ N0 dose: } \\
\hline year & $0.686(0.000)$ & $0.375(0.001)$ & & $0.368(0.021)$ \\
\hline season & $0.528(0.000)$ & $0.000(0.989)$ & & \\
\hline organic amendment & $0.573(0.000)$ & $0.331(0.008)$ & $0.785(0.000)$ & $0.544(0.009)$ \\
\hline \multicolumn{5}{|l|}{ N1 dose: } \\
\hline year & $0.517(0.000)$ & $0.305(0.003)$ & & $0.809(0.000)$ \\
\hline season & $0.369(0.001)$ & $0.364(0.001)$ & & \\
\hline organic amendment & $0.135(0.176)$ & $0.334(0.008)$ & $0.367(0.004)$ & $0.692(0.001)$ \\
\hline \multicolumn{5}{|l|}{ N2 dose: } \\
\hline year & $0.488(0.000)$ & $0.000(0.961)$ & & $0.681(0.000)$ \\
\hline season & $0.435(0.000)$ & $0.013(0.576)$ & & \\
\hline organic amendment & $0.437(0.001)$ & $0.518(0.000)$ & $0.592(0.000)$ & $0.055(0.710)$ \\
\hline \multicolumn{5}{|l|}{ N3 dose: } \\
\hline year & $0.676(0.000)$ & $0.004(0.771)$ & & $0.755(0.000)$ \\
\hline season & $0.406(0.000)$ & $0.001(0.908)$ & & \\
\hline organic amendment & $0.319(0.010)$ & $0.559(0.000)$ & $0.622(0.000)$ & $0.145(0.392)$ \\
\hline \multicolumn{5}{|l|}{ N4 dose: } \\
\hline year & $0.599(0.000)$ & $0.113(0.093)$ & & $0.747(0.000)$ \\
\hline season & $0.610(0.000)$ & $0.010(0.625)$ & & \\
\hline organic amendment & $0.237(0.039)$ & $0.520(0.000)$ & $0.502(0.000)$ & $0.026(0.845)$ \\
\hline
\end{tabular}


Correlations between AS, MBC, SOC and grain yield were investigated using Pearson correlation analysis (Table 4). There is a weak (0.173) but significant correlation between AS and MBC. In addition to correlating with AS, MBC is significantly correlated with SOC (0.339). There is no correlation between SOC and AS. Examination of the relationship between grain yield and SOC showed a weak (0.274) significant correlation. The grain yield did not correlate with AS or MBC. The winter wheat (in 2015) and the winter barley (in 2016) have different average grain yields (6.4 and $4.0 \mathrm{t}^{*} \mathrm{ha}^{-1}$, respectively). This difference can create misleading results from the correlation analysis. Therefore, the values of grain yields were normalized, and these normalized values were used in the correlation analysis. Table 4 shows the yearly (2015 and 2016) correlation coefficients too.

Table 4. Correlation coefficients between the aggregate stability (AS), microbial biomass C (MBC), soil organic carbon (SOC) and normalized grain yields. Significance values are in parenthesis. $n$ (numbers of data) is 180, except the normalized crop yields, where $n$ is 90 , because only the autumn values were used.

\begin{tabular}{cccc}
\hline & $\begin{array}{c}\text { MBC } \\
\text { Total } \\
\text { Year 2015 } \\
\text { Year 2016 }\end{array}$ & $\begin{array}{c}\text { SOC } \\
\text { Total } \\
\text { Year 2015 } \\
\text { Year 2016 }\end{array}$ & $\begin{array}{c}\text { Norm. Grain Yield } \\
\text { Total } \\
\text { Year 2015 } \\
\text { Year 2016 }\end{array}$ \\
\hline AS & & & \\
total & $0.173(0.020)$ & $-0.055(0.466)$ & $0.113(0.291)$ \\
year 2015 & $-0.122(0.252)$ & $-0.087(0.416)$ & $0.123(0.422)$ \\
year 2016 & $0.265(0.012)$ & $-0.046(0.667)$ & $0.189(0.215)$ \\
MBC & & & \\
total & & $0.339(0.000)$ & $0.056(0.597)$ \\
year 2015 & & $0.555(0.000)$ & $0.223(0.142)$ \\
year 2016 & & $0.170(0.109)$ & $-0.093(0.544)$ \\
SOC & & & $0.274(0.009)$ \\
total & & & $0.404(0.006)$ \\
year 2015 & & & $0.145(0.343)$ \\
year 2016 & & & \\
\hline
\end{tabular}

\section{Discussion}

\subsection{Effects of Year and Season on AS}

The amount of stable aggregates and microbial biomass show spatial and temporal variances in soils. Both $\mathrm{AS}$ and $\mathrm{MBC}$ are quickly variable in time, compared to the slow changing SOM content. The size of temporal variances and the trend of seasonality vary in the different publications. In our experiments AS showed significant variance, taking all data into account the CV was $25 \%$ (Table 1 ). This $C V$ value ranks as moderate, and corresponds to that described in other studies [58,59]. The variance of AS, based on partial Eta squared, was primarily determined by the year (0.592) and the season (0.470). To a lesser extent the effect of organic amendment can be detected (0.111). Bottinelli et al. (2017) also stated, that the seasonal variation observed in AS was more significant than the variation due to the effect of management practices (tillage, fertilization) [60]. The organic amendment also had a significant interaction with the $\mathrm{N}$ fertilizer dose (partial Eta squared: 0.302). The interactions between the year and the other factors are not significant in cases of AS. The significant effect of the year is also due to the fact that in our experiment the year factor meant another crop too. In our experiment the averages of aggregate stability (AS) were higher in spring than in autumn and these differences are significant. Our results are consistent with the results of other works $[12,60]$. They observed a steady increase in aggregate stability from March to June. We did not have enough sampling time to make a similar statement. 


\subsection{Effects of Year and Season on $M B C$}

When calculating the joint data of the two years, the averages of $\mathrm{MBC}$ in spring and autumn did not differ significantly from each other, as the seasonality of MBC differed in the two years. The averages of microbial biomass were higher in the autumn of 2015, than in spring, but in 2016 the scheme was the opposite (Table 1). Wardle (1998) in his comparative assessment did not find a general tendency for seasonal changes of microbial biomass [40]. His conclusion was that the microbial biomass is usually highest in spring or autumn, or there is no clear tendency. Our results also support that there is no generalizable trend for the changing of MBC. Taking all our data into account, CV of MBC was 34.8\% (Table 1). The CV values of MBC obtained in our experiment remained within the limits (ranging from 7.6 to $49.3 \%$ ) reported by Wardle (1998) [40]. The variance of MBC, based on partial Eta squared was primarily determined by organic amendment (0.439), year (0.130) and some year interactions. Season and $\mathrm{N}$ fertilizer dose had no considerable effect on MBC. Comparing to AS, the year and season had much less effect on the variability of MBC. In a three-year study (IOSDV Berlin-Dahlem) microbial biomass contents in the treatments were significantly higher in summer than in spring in two years, but in one year no seasonal effect was observed [51]. Spedding et al. (2004) reported that soil MBC showed no seasonal fluctuation at $0-10 \mathrm{~cm}$ but were highest in May at 10-20 $\mathrm{cm}$ in their experiment, where the samples were taken four times a year (May, June, July and September) [41]. Soil $\mathrm{MBC}$ showed little variation throughout the growing season, soil microbial biomass $\mathrm{N}$ (MBN) was more temporally variable [41].

\subsection{Effects of Organic Amendments on AS}

Three kinds of organic amendment treatment were applied in the IOSDV experiment. Straw was removed and there was no added organic matter in the "No" treatment; straw was removed but farmyard manure was added in the "Manure" treatment (once every three years); and straw was incorporated but there was no added farmyard manure in the "Straw" treatment. This set-up allows the investigation of the effects of the different organic amendments. The soil improving effect of organic manure and straw incorporation are widely accepted [27-29]. Organic amendments had significant effects on both the AS and MBC in our experiment but their effects were different. Both forms of organic amendment increased the AS to a certain extent, but only the effect of straw incorporation was significant. This change in AS differs from the change in MBC and SOC, where the manure had the most increasing effect. Our results are in agreement with ideas of DiGléria et al. (1957, cit Huisz 2002) and the results of Long et al. (2015), who stated that poultry manure only had a small influence $[32,33,61]$. There are also publications contrary to our results in which manure has a greater effect then straw incorporation [29,62]. The differences in the organic $C$ content and the dose of manure or straw applied might explain the different conclusions. The applied dose in our experiment, $35 \mathrm{t}$ farmyard manure $\mathrm{ha}^{-1}$ in every third year, counts as a moderate or low dose. The effect of organic amendment (partial Eta squared 0.111) on AS was smaller than year and season $(0.592$ and 0.470 , respectively). The organic amendment ${ }^{*} \mathrm{~N}$ fertilization dose interaction had a comparable effect (0.302) on AS and this points to the importance of the amendment dose.

\subsection{Effects of Organic Amendments on MBC}

Organic amendments usually increase MBC in soils, depending on the form of the organic amendment and the circumstances (soil properties, managements, climate). Both forms of organic amendment significantly increased $\mathrm{MBC}$, to the highest degree in the manure treatment in our experiments. Kautz et al. (2004) reported that in a similar IOSDV experiment (near Berlin-Dahlem, Germany) the highest soil microbial biomass carbon content was generally found in the treatments with straw incorporation and green manure [51]. They reported comparably week effects of farmyard manure on soil microbial biomass. Kautz et al. (2004) assumed that the farmyard manure was mostly decomposed at the time of the investigation, thus, no direct impact on soil biomass was detected [51]. 
Their article did not contain SOC content measurements, thus the long-term effect of manure and straw incorporation remained unexplained. The structure and treatments of IOSDV experiment near Berlin-Dahlem is similar to that of our study, but the crops and consequently, the doses of fertilizers are different. Our experiment is similar to that of Kautz et al. (2004) in that the time of our measurements also fell on the second and third years after manure application. In our experiments manure addition significantly increased the MBC. This result is in contrast to that of Kautz et al. (2004) [51], but is in agreement with the results of other investigations [42,63]. The increasing effect of straw incorporation on $\mathrm{MBC}$ is also widely accepted, although some authors report a lack of effect. Spedding et al. (2004) stated that residue management increased soil MBC and MBN levels in plots with straw incorporation, but there were significant only at 0-10 cm [41]. Simon et al. (2012) reported that organic amendments (organic manure or straw incorporation) increased MBC by $7-27 \%$, but these changes were not significant [64].

The temporal variability of AS and MBC were investigated in the two years of sampling (Table 1). Presumably due to the different seasonal variability and the different effect of organic amendments, we did not obtain a significant correlation between AS and MBC. A further explanation for the lack of correlation between AS and MBC may be that AM fungi play a major role in increasing aggregate stability [19,20]. However, AMF constitute only a small and variable fraction of soil microbial biomass.

\subsection{Effects of Organic Amendments on SOC}

Organic amendments are fundamental to maintain or increase the SOM [33]. The effect of different amendments on SOC varies in the literature. Diacono and Montemurro (2010) stated that only farmyard manure fertilization maintained the total organic carbon level of $40 \mathrm{tC}^{*} \mathrm{ha}^{-1}$, measured in the top soil layers at the start of a 40-year experiment [39]. Boguzas et al. (2015) reported that continuous long term straw application (12-14 years) increased SOC content by $9.3-12.0 \%$ compared to the plots without straw [65]. Liu et al. (2013) reported that SOC concentration in surface soil $(0-20 \mathrm{~cm})$ and SOC storage of the profile $(0-100 \mathrm{~cm})$ were not significantly or slightly increased by the 30 years of mineral fertilizer treatments, but they were sharply increased by the manure amendment or straw incorporation [62]. Berhane et al. (2020) in their meta-analysis found that NPK+manure treatments had greater increasing effects on SOC than NPK+straw incorporation [66]. In our experiment the straw incorporation did not increase the SOC significantly, but manure increased SOC significantly compared to straw incorporation or to mineral fertilization (Table 1). Our results reveal that the effect of manure is greater than that of straw incorporation, which are similar to the results of other works [61,63,67]. Stehlikova et al. (2016) also found similar patterns, but in their experiments (IOSDV, Ivanovice na Hané, Czech Republic) the differences between the treatments were not significant [49].

The effects of organic amendment were contradictory in our experiment. On the one hand, farmyard manure did not increase AS or grain yield in the years investigated, and on the other hand it increased SOC in the long run. This pointed out the fact if the change of SOC caused is relatively small, the quality of the SOM and the maturation processes of the manure in the soil can be very important. Simon et al. (2012) highlight the importance of humus quality. In their long-term fertilization experiment the farmyard manure and straw incorporation increased the SOC by $28-32 \%$, and $10-12 \%$, respectively, compared to the unamended control [64].

\subsection{Effects of Organic Amendments on Grain Yield}

Hijbeek et al. (2017) performed a meta-analysis using data from 20 long-term experiments (including IOSDVs from different locations: Keszthely, Novi Sad, Puch, Speyer, Tartu, Wienna) in Europe [44]. They were surprised to discover that, across all experiments, the mean additional yield effect of organic inputs was not significant. Our results (Table 1 ) are consistent with the results of Hijbeek et al. (2017), manure or straw incorporation did not cause a significant increase in grain yield averages compared to the un-amended control. 
It was concluded that organic inputs did not necessarily increase yields, given sufficient nutrients were supplied by mineral fertilizers, and our results supported this finding. The effect size of organic amendment was high and significant when the treatments receiving lower N fertilizer doses (N0-N2) were examined separately, while at higher N fertilizer doses (N3-N4), the effect size of organic amendment was small and not significant (Table 3). The results showed the relevance of some environmental factors for additional yield effect of organic inputs, but no simple relation between organic inputs and crop growth [44].

\subsection{Effects of $N$ Fertilization on AS, MBC, SOC and Grain Yield}

The dose of $\mathrm{N}$ fertilization had not significant effect on AS nor MBC in our experiment, but it significantly increased SOC and grain yield. Among the investigated factors, N fertilizer dose had the largest effect size (partial Eta squared 0.597) on grain yield. The positive effect of $\mathrm{N}$ fertilization on SOC in agroecosystems is well recognized [68]. It is also generally accepted, that is mainly an input-driven effect. Higher yield means more plant material (crop residues, rhizodeposits, roots) input into the soil. Correlation were frequently found between yield, plant input and soil microbial biomass. In our experiment we did not find such significant correlation (Table 4). However, the increased amount of plant input into the soil (due to $\mathrm{N}$ fertilization) increased the amount of SOC in the long run (from 1983 to 2013). This SOC change was not indicated by MBC in our experiment, contrary to that described by Powlson et al. (1987), who hypothesized the role of MBC predicting SOC changes [69]. According to a recent literature review the relative effect of yield on SOC changes is not always detectable [68].

\section{Conclusions}

In the 32nd and 33rd years of an IOSDV long-term fertilization experiment, the effect of organic amendments and $\mathrm{N}$ fertilization on $\mathrm{AS}, \mathrm{MBC}, \mathrm{SOC}$, and grain yield were investigated. Organic amendments affected AS and MBC differently. AS was increased the most by straw incorporation, while MBC was increased the most by farmyard manure. The dose of $\mathrm{N}$ fertilization neither had significant effect on AS nor MBC in our experiment, but it significantly increased SOC and grain yield. In addition to the long-term effects, the seasonal fluctuations of AS and MBC were also investigated in the two years of sampling. MBC showed greater variability than AS, based on CV values. Presumably due to the different seasonal variability and the different effect of organic amendments, we did not obtain a significant correlation between AS and MBC. The results of studies examining the interactions of AS, MBC, SOM and fertilization are frequently controversial, so there is a need for long-term fertilization experiments, especially those set up according to a uniform principle in different locations (e.g., IOSDV) and as frequent sampling as possible.

Author Contributions: Conceptualization, G.C., Z.T. and M.K.; methodology, G.C., Z.T. and M.K.; investigation, G.C. and M.K.; resources, G.C. and Z.T.; writing-original draft preparation, G.C. and Z.T.; project administration, G.C. and Z.T., funding acquisition, G.C. and Z.T.; All authors have read and agreed to the published version of the manuscript.

Funding: The research was supported by the EFOP-3.6.3-VEKOP-16-2017-00008 project. The project is co-financed by the European Union and the European Social Fund. The publication was supported by the European Union under Horizon-2020-SFS-2015-2 Program grant agreement No. 677407 (SOILCARE project, https:/ / www.soilcare-project.eu/ (accessed on 17 August 2021)).

Acknowledgments: The authors wish to thank Csütörtökiné Rigó Erzsébet for laboratory work.

Conflicts of Interest: The authors declare no conflict of interest.

\section{References}

1. Amézketa, E. Soil aggregate stability: A review. J. Sustain. Agric. 1999, 14, 83-151. [CrossRef]

2. Miller, R.M.; Jastrow, J.D. Mycorrhizal Fungi Influence Soil Structure. In Arbuscular Mycorrhizas: Physiology and Function; Springer: Dordrecht, The Netherlands, 2000; pp. 3-18. 
3. Wilpiszeski, R.L.; Aufrecht, J.A.; Retterer, S.T.; Sullivan, M.B.; Graham, D.E.; Pierce, E.M.; Zablocki, O.D.; Palumbo, A.V.; Elias, D.A. Soil aggregate microbial communities: Towards understanding microbiome interactions at biologically relevant scales. Appl. Environ. Microbiol. 2019, 85, e00324-19. [CrossRef] [PubMed]

4. Tisdall, J.M.; Oades, J.M. Organic matter and water-stable aggregates in soils. J. Soil Sci. 1982, 33, 141-163. [CrossRef]

5. Nichols, K.A.; Halvorson, J.J. Roles of biology, chemistry, and physics in soil macroaggregate formation and stabilization. Open Agric. J. 2013, 7, 107-117. [CrossRef]

6. Perfect, E.; Kay, B.D.; van Loon, W.K.P.; Sheard, R.W.; Pojasok, T. Factors influencing soil structural stability within a growing season. Soil Sci. Soc. Am. J. 1990, 54, 173-179. [CrossRef]

7. Cosentino, D.; Chenu, C.; Le Bissonnais, Y. Aggregate stability and microbial community dynamics under drying-wetting cycles in a silt loam soil. Soil Biol. Biochem. 2006, 38, 2053-2062. [CrossRef]

8. Chan, K.Y.; Heenan, D.P.; Ashley, R. Seasonal changes in surface aggregate stability under different tillage and crops. Soil Tillage Res. 1994, 28, 301-314. [CrossRef]

9. Bullock, M.S.; Kemper, W.D.; Nelson, S.D. Soil cohesion as affected by freezing, water content, time and tillage. Soil Sci. Soc. Am. J. 1988, 52, 770-776. [CrossRef]

10. Blackman, J.D. Seasonal variation in the aggregate stability of downland soils. Soil Use Manag. 1992, 8, 142-150. [CrossRef]

11. Lehrsch, G.A.; Jolley, P.M. Temporal changes in wet aggregate stability. Trans. Am. Soc. Agric. Eng. 1992, 35, 493-498. [CrossRef]

12. Mulla, D.J.; Huyck, L.M.; Reganold, J.P. Temporal variation in aggregate stability on conventional and alternative farms. Soil Sci. Soc. Am. J. 1992, 56, 1620-1624. [CrossRef]

13. Linsler, D.; Taube, F.; Geisseler, D.; Joergensen, R.G.; Ludwig, B. Temporal variations of the distribution of water-stable aggregates, microbial biomass and ergosterol in temperate grassland soils with different cultivation histories. Geoderma 2015, 241-242, 221-229. [CrossRef]

14. Bach, E.M.; Hofmockel, K.S. A time for every season: Soil aggregate turnover stimulates decomposition and reduces carbon loss in grasslands managed for bioenergy. GCB Bioenergy 2016, 8, 588-599. [CrossRef]

15. Aksakal, E.L.; Barik, K.; Angin, I.; Sari, S.; Islam, K.R. Spatio-temporal variability in physical properties of different textured soils under similar management and semi-arid climatic conditions. Catena 2019, 172, 528-546. [CrossRef]

16. Jiang, H.; Han, X.; Zou, W.; Hao, X.; Zhang, B. Seasonal and long-term changes in soil physical properties and organic carbon fractions as affected by manure application rates in the Mollisol region of Northeast China. Agric. Ecosyst. Environ. 2018, 268, 133-143. [CrossRef]

17. Habib, L.; Morel, J.L.; Guckert, A.; Plantureux, S.; Chenu, C. Influence of root exudates on soil aggregation. Symbiosis 1990, 9 , 87-91.

18. Morel, J.L.; Habib, L.; Plantureux, S.; Guckert, A. Influence of maize root mucilage on soil aggregate stability. Plant Soil 1991, 136, 111-139. [CrossRef]

19. Ritz, K.; Young, I.M. Interactions between soil structure and fungi. Mycologist 2004, 18, 52-59. [CrossRef]

20. Rillig, M.C.; Mummey, D.L. Mycorrhizas and soil structure. New Phytol. 2006, 171, 41-53. [CrossRef] [PubMed]

21. Bronick, C.J.; Lal, R. Soil structure and management: A review. Geoderma 2005, 124, 3-22. [CrossRef]

22. Chenu, C.; Cosentino, D. Microbial regulation of soil structural dynamics. In The Architecture and Biology of Soils: Life in Inner Space; Ritz, K., Young, I., Eds.; CABI: Oxfordshire, UK, 2011; pp. 37-70.

23. Piccolo, A. Humus and Soil Conservation. In Humic Substances in Terrestrial Ecosystems; Elsevier: Amsterdam, The Netherlands, 1996; pp. 225-264.

24. Yu, H.; Ding, W.; Luo, J.; Geng, R.; Cai, Z. Long-term application of organic manure and mineral fertilizers on aggregation and aggregate-associated carbon in a sandy loam soil. Soil Tillage Res. 2012, 124, 170-174. [CrossRef]

25. Zhang, J.; Sun, C.; Liu, G.; Xue, S. Effects of long-term fertilisation on aggregates and dynamics of soil organic carbon in a semi-arid agro-ecosystem in China. PeerJ 2018, 2018, 1-20. [CrossRef]

26. Abiven, S.; Menasseri, S.; Angers, D.A.; Leterme, P. A Model to Predict Soil Aggregate Stability Dynamics following Organic Residue Incorporation under Field Conditions. Soil Sci. Soc. Am. J. 2008, 72, 119-125. [CrossRef]

27. Larney, F.J.; Angers, D.A. The role of organic amendments in soil reclamation: A review. Can. J. Soil Sci. 2012, 92, 19-38. [CrossRef]

28. Scotti, R.; Bonanomi, G.; Scelza, R.; Zoina, A.; Rao, M.A. Organic amendments as sustainable tool to recovery fertility in intensive agricultural systems. J. Soil Sci. Plant Nutr. 2015, 15, 333-352. [CrossRef]

29. Abiven, S.; Menasseri, S.; Chenu, C. The effects of organic inputs over time on soil aggregate stability-A literature analysis. Soil Biol. Biochem. 2009, 41, 1-12. [CrossRef]

30. Bai, Z.; Caspari, T.; Gonzalez, M.R.; Batjes, N.H.; Mäder, P.; Bünemann, E.K.; de Goede, R.; Brussaard, L.; Xu, M.; Ferreira, C.S.S.; et al. Effects of agricultural management practices on soil quality: A review of long-term experiments for Europe and China. Agric. Ecosyst. Environ. 2018, 265, 1-7. [CrossRef]

31. Sarker, T.C.; Incerti, G.; Spaccini, R.; Piccolo, A.; Mazzoleni, S.; Bonanomi, G. Linking organic matter chemistry with soil aggregate stability: Insight from 13C NMR spectroscopy. Soil Biol. Biochem. 2018, 117, 175-184. [CrossRef]

32. Di Gléria, J.; Klimes-Szmik, A.; Dvoracsek, M. Talajfizika és Kolloidika; Akadémiai Kiadó: Budapest, Hungary, 1957.

33. Huisz, A. Characterization of Changes in Soil Structure and Redistribution of Soil Organic Amtter by New Methods in Long-Term Tillage Experiments. PhD Thesis, University of Debrecen, Debrecen, Hungary, 2012. 
34. Sparling, G.P. Soil microbial biomass, activity and nutrient cycling as indicators of soil health. In Biological Indicators of Soil Health; CABI: Oxfordshire, UK, 1997; pp. 97-119. ISBN 0-85199-158-0.

35. Haynes, R.J. Soil organic matter quality and the size and activity of the microbial biomass: Their significance to the quality of agricultural soils. In Soil Mineral Microbe-Organic Interactions: Theories and Applications; Springer: New York, NY, USA, 2008; pp. 201-231; ISBN 9783540776857.

36. Wardle, D.A. A comparative assessment of factors which influence microbial biomass carbon and nitrogen levels in soil. Biol. Rev. Camb. Philos. Soc. 1992, 67, 321-358. [CrossRef]

37. Fierer, N.; Strickland, M.S.; Liptzin, D.; Bradford, M.A.; Cleveland, C.C. Global patterns in belowground communities. Ecol. Lett. 2009, 12, 1238-1249. [CrossRef]

38. Soong, J.L.; Fuchslueger, L.; Marañon-Jimenez, S.; Torn, M.S.; Janssens, I.A.; Penuelas, J.; Richter, A. Microbial carbon limitation: The need for integrating microorganisms into our understanding of ecosystem carbon cycling. Glob. Chang. Biol. 2020, 26, 1953-1961. [CrossRef] [PubMed]

39. Diacono, M.; Montemurro, F. Long-term effects of organic amendments on soil fertility. A review. Agron. Sustain. Dev. 2010, 30, 401-422. [CrossRef]

40. Wardle, D.A. Controls of temporal variability of the soil microbial biomass: A global-scale synthesis. Soil Biol. Biochem. 1998, 30, 1627-1637. [CrossRef]

41. Spedding, T.A.; Hamel, C.; Mehuys, G.R.; Madramootoo, C.A. Soil microbial dynamics in maize-growing soil under different tillage and residue management systems. Soil Biol. Biochem. 2004, 36, 499-512. [CrossRef]

42. Kallenbach, C.; Grandy, A.S. Controls over soil microbial biomass responses to carbon amendments in agricultural systems: A meta-analysis. Agric. Ecosyst. Environ. 2011, 144, 241-252. [CrossRef]

43. Geisseler, D.; Scow, K.M. Long-term effects of mineral fertilizers on soil microorganisms-A review. Soil Biol. Biochem. 2014, 75, 54-63. [CrossRef]

44. Hijbeek, R.; van Ittersum, M.K.; ten Berge, H.F.M.; Gort, G.; Spiegel, H.; Whitmore, A.P. Do organic inputs matter-A metaanalysis of additional yield effects for arable crops in Europe. Plant Soil 2017, 411, 293-303. [CrossRef]

45. Körschens, M.; Albert, E.; Armbruster, M.; Barkusky, D.; Baumecker, M.; Behle-Schalk, L.; Bischoff, R.; Čergan, Z.; Ellmer, F.; Herbst, F; i et al. Effect of mineral and organic fertilization on crop yield, nitrogen uptake, carbon and nitrogen balances, as well as soil organic carbon content and dynamics: Results from 20 European long-term field experiments of the twenty-first century. Arch. Agron. Soil Sci. 2013, 59, 1017-1040. [CrossRef]

46. Spiegel, H.; Dersch, G.; Baumgarten, A.; Hösch, J. The international organic nitrogen long-term fertilisation experiment (IOSDV) at Vienna after 21 years. Arch. Agron. Soil Sci. 2010, 56, 405-420. [CrossRef]

47. Tajnšek, A.; Čergan, Z.; Čeh, B. Results of the long-term field experiment IOSDV Jable at the beginning of the 21st century. Arch. Agron. Soil Sci. 2013, 59, 1099-1108. [CrossRef]

48. Kismányoky, T.; Tóth, Z. Effect of mineral and organic fertilization on soil organic carbon content as well as on grain production of cereals in the IOSDV (ILTE) long-term field experiment, Keszthely, Hungary. Arch. Agron. Soil Sci. 2013, 59, 1121-1131. [CrossRef]

49. Stehlíková, I.; Madaras, M.; Lipavský, J.; Šimon, T. Study on some soil quality changes obtained from long-term experiments. Plant Soil Environ. 2016, 62, 74-79. [CrossRef]

50. Are, M.; Kaart, T.; Selge, A.; Astover, A.; Reintam, E. The interaction of soil aggregate stability with other soil properties as influenced by manure and nitrogen fertilization. Zemdirbyste 2018, 105, 195-202. [CrossRef]

51. Kautz, T.; Wirth, S.; Ellmer, F. Microbial activity in a sandy arable soil is governed by the fertilization regime. Eur. J. Soil Biol. 2004, 40, 87-94. [CrossRef]

52. Csathó, P.; Magyar, M.; Debreczeni, K.; Sárdi, K. Correlation between soil P and wheat shoot P contents in a network of Hungarian long-term field trials. Commun. Soil Sci. Plant Anal. 2005, 36, 275-293. [CrossRef]

53. Kismányoky, T.; Balázs, J. Keszthely, Long-Term Field Experiments; Kismányoky, T., Balázs, J., Eds.; Pannon University: Veszprém, Keszthely, 1996.

54. Vance, E.D.; Brookes, P.C.; Jenkinson, D.S. An extraction method for measuring soil microbial biomass C. Soil Biol. Biochem. 1987, 19, 703-707. [CrossRef]

55. Kemper, W.D.; Koch, E.J. Aggregate Stability of Soils from Western United States and Canada. Measurement Procedure, Correlation with Soil Constituents; US Department of Agriculture: North Bend, WA, USA, 1966; pp. 29-30.

56. MSz-08-0210-1977. A Talaj Szerves Széntartalmának Meghatározása, Magyar Szabvány (Testing Organic Carbon Content in Soils, Hungarian Standard); Hungarian Standard Institution: Budapest, Hungary, 1977.

57. Tyurin, I.V. A new modification of the volumetric method of determining soil organic matter by means of chromic acid. Pochvovedenie 1931, 26, 36-47.

58. Heshmati, M.; Abdu, A.; Jusop, S.; Majid, N.M. Effects of land use practices on the organic carbon content, cation Exchange capacity and aggregate stability of soils in the catchment zones. Am. J. Appl. Sci. 2011, 8, 1363-1373. [CrossRef]

59. Algayer, B.; Le Bissonnais, Y.; Darboux, F.; Algayer, B.; Le Bissonnais, Y.; Darboux, F. Short-term dynamics of soil aggregate stability in the field. Soil Sci. Soc. Am. J. 2014, 78, 1168-1176. [CrossRef]

60. Bottinelli, N.; Angers, D.A.; Hallaire, V.; Michot, D.; Le Guillou, C.; Cluzeau, D.; Heddadj, D.; Menasseri-Aubry, S. Tillage and fertilization practices affect soil aggregate stability in a Humic Cambisol of Northwest France. Soil Tillage Res. 2017, 170, 14-17. [CrossRef] 
61. Long, P.; Sui, P.; Gao, W.S.; Wang, B.B.; Huang, J.X.; Yan, P.; Zou, J.X.; Yan, L.L.; Chen, Y.Q. Aggregate stability and associated C and $\mathrm{N}$ in a silty loam soil as affected by organic material inputs. J. Integr. Agric. 2015, 14, 774-787. [CrossRef]

62. Liu, E.; Yan, C.; Mei, X.; Zhang, Y.; Fan, T. Long-term effect of manure and fertilizer on soil organic carbon pools in dryland farming in Northwest China. PLoS ONE 2013, 8, e56536. [CrossRef]

63. Marschner, P.; Kandeler, E.; Marschner, B. Structure and function of the soil microbial community in a long-term fertilizer experiment. Soil Biol. Biochem. 2003, 35, 453-461. [CrossRef]

64. Šimon, T.; Mikanová, O.; Cerhanová, D. Long-term effect of straw and farmyard manure on soil organic matter in field experiment in the Czech Republic. Arch. Agron. Soil Sci. 2013, 59, 1-13. [CrossRef]

65. Bogužas, V.; Mikučionienè, R.; Šlepetienè, A.; Sinkevičienè, A.; Feiza, V.; Steponavičienè, V.; Adamavičienè, A. Long-term effect of tillage systems, straw and green manure combinations on soil organic matter. Zemdirbyste 2015, 102, 243-250. [CrossRef]

66. Berhane, M.; Xu, M.; Liang, Z.; Shi, J.; Wei, G.; Tian, X. Effects of long-term straw return on soil organic carbon storage and sequestration rate in North China upland crops: A meta-analysis. Glob. Chang. Biol. 2020, 26, 2686-2701. [CrossRef] [PubMed]

67. Lipavský, J.; Kubát, J.; Zobač, J. Long-term effects of straw and farmyard manure on crop yields and soil properties. Arch. Agron. Soil Sci. 2008, 54, 369-379. [CrossRef]

68. Bolinder, M.A.; Crotty, F.; Elsen, A.; Frac, M.; Kismányoky, T.; Lipiec, J.; Tits, M.; Tóth, Z.; Kätterer, T. The effect of crop residues, cover crops, manures and nitrogen fertilization on soil organic carbon changes in agroecosystems: A synthesis of reviews. Mitig. Adapt. Strateg. Glob. Chang. 2020, 25, 929-952. [CrossRef]

69. Powlson, D.S.; Prookes, P.C.; Christensen, B.T. Measurement of soil microbial biomass provides an early indication of changes in total soil organic matter due to straw incorporation. Soil Biol. Biochem. 1987, 19, 159-164. [CrossRef] 